\title{
The Models for Growth Process of Spruce-fir Forest
}

\author{
Mengtao Zhang,Xingang Kang \\ Department of Forestry \\ Beijing Forestry University \\ Beijing, China, 100083
}

\author{
Shuo Cai \\ Department of Forestry \\ Beijing Forestry University \\ Beijing, China, 100083
}

\begin{abstract}
Pass in the Wang Qing in Jilin province Jingouling forestry station to establish temporary study plot, carried on stem analysis, analysis spruce-fir wildwood growth process, discovered spruce-fir DBH for current annual increment at hit maximum for 50 years and 100 years, respectively is $1.14 \mathrm{~cm}$ and $1.07 \mathrm{~cm}$.Height of tree current annual increment at 30 years and 75 years maximum, respectively is $0.49 \mathrm{~m}$ and $0.66 \mathrm{~m}$. In spruce-fir volume of wood growth process, volume of wood current annual increment is higher than average increment. The Quadratic can the good fitting spruce-fir height curve, secondly is Logarithmic, their correlation coefficient respectively is $0.985,0.982$ and $0.979,0.935$.
\end{abstract}

Keywords-Spruce-fir wildwood, Growth process, DBH, Tree height, Tree volume

\section{INTRODUCTION}

The natural forest is the corpus of forest resources, in the ecosystem efficiency and the social efficiency it plays an irreplaceable role, while also providing a variety of production and life of our wood and forest products, which is important material foundation of the survival and development of human [1]. The spruce-fir forest is a widespread dark coniferous forest's constituent in North variable zone of our country. By the spruce, the fir tree to mainly construct a group kind of dark coniferous forest generally is the mountainous region vertical climatic zone of the forest type, which widely distributed in the mountain areas of Northeast China, North Mountain, Qin Ling Mountains, Mongolia- Xinjiang Mountains and Mountainous eastern and southern margins of the Tibetan Plateau. It's also natural-distributed in Taiwan [2]. As a kind of cold temperate evergreen coniferous forest is most widely distributed, it provides a variety of national economies development, and important raw materials for paper and man-made fibers; on the other hand, spruce-fir forest also plays an important role in terms of saving of water, conserving of water and soil, maintaining the ecological balance of the surrounding area, improving the ecological environment and ensuring normal industrial and agricultural production [3]

At present, the research of spruce-fir growth mainly focuses on two aspects: one is individual tree and forest stand growth, another one is effects of environments and management measures on growth of tree species [4] Therefore, studying of growth of spruce-fir, not only can supply the difference of different origins stand in growth of trees, but provide a more complete, rich scientific basis for understanding a dynamics growth about spruce-fir. Sprucefir natural forest is one of the main types in Changbai Mountains, in recent years, forest workers carried on a lot of research about spruce-fir stand structure growth, and accumulated very valuable experience, but the study of dynamic growth process of single tree in spruce-fir natural forests is relatively few. This paper analyze existing data of stem analysis of spruce and fir, and reveal correlation of their breast height diameter, height of tree, volume of wood, to mastering the spruce-fir natural forest growth dynamics, and provide reasonable and effective reference for constituting relevant management measures.

\section{RESEARCH AREA OVERVIER}

Study area is located in north eastern Jilin Province Wangqing County Jingouling tree farm, which longitude $130^{\circ} 10^{\prime}$, latitude $43^{\circ} 22^{\prime}, 59 \mathrm{~km}$ away from the county. Department of forest is located in the Changbai Mountains, surrounded by mountains, border with the Huanggou Forest east,west Tazigou and Qinghe Forest, north Diyingou and Shiliping south. Topography of forest is hilly, altitude of $300 \mathrm{~m} \sim 1200 \mathrm{~m}$, slope in $5^{\circ} \sim 25^{\circ}$, only a few in $35^{\circ}$ or more. Climate is monsoon type, the average annual temperature is about $3.9{ }^{\circ} \mathrm{C}$, accumulated temperature $2144{ }^{\circ} \mathrm{C}$; The lowest temperatures in January, an average of about $-32{ }^{\circ} \mathrm{C}$; The highest temperature in July, an average of about $22{ }^{\circ} \mathrm{C}$, annual rainfall $600 \mathrm{~mm} \sim$ $700 \mathrm{~mm}$.

\section{MATERIALS ANDMETHODS}

Data comes from clear cutting plot set the sample plot $20 \mathrm{~m} \times 20 \mathrm{~m}$ of compartment No. 37 in Jingouling in 1986 to 1988 . In the standard plot, each spruce and fir was measured by DBH. A spruce and a fir were selected according to the average level, (finally 14 trees were chosen) then cutting down for stem analysis. According to the standard wooden analysis law, the analytic tree was divided to sections of $2 \mathrm{~m}$ disc was intercepted there, conventional method was used in measuring growth ring and diameter, tree height was derived from chat of age gradation and height $[5,6]$, tree volume, form factor etc can be calculated after that.

The formula of volume growth rate: formula of form factor: 


$$
\begin{gathered}
P v=\frac{V_{a}-V_{a-n}}{V_{a}+V_{a-n}} \cdot \frac{200}{n} \\
f_{1.3}=\frac{V}{g_{1.3} h} \\
\text { (Pressler 1857) } \\
\mathrm{P} \text { v }- \text { Volume growth rate; } \mathrm{V}-\text { tree volume; } \\
\mathrm{V} \text { a }- \text { Final volume in survey; } \mathrm{h}-\text { tree height; } \\
\mathrm{V} \text { a-n } \mathrm{n} \text { - Initial volume in survey; }
\end{gathered}
$$

Use EXCEL、SPSS to analyze the relationship of DBH, height and volume, then simulate and select out the most appropriate diameter-height curve.

\section{RESULT AND ANALYSIS}

\section{A. growth analysis}

After the stem analysis of spruce-fir sample woods, results of the diameter, height, volume growth and other basic data are shown in Table 1-2

\section{B. analysis of spruce-fir $d b h$}

As shown in the growth table (Table I\&Table II) and the graph of current diameter and mean annual increment (Figure 1\& Figure 2): The maximum current annual increment of DBH of spruce tree showed in 50 years, as $1.14 \mathrm{~cm}$, and the maximum mean annual increment showed in 70 years, as $0.68 \mathrm{~cm}$. Between 20 and 40 years, DBH growth began to accelerate, while from 40 to 70 years, the growth of $\mathrm{DBH}$ achieved strong, after 70 years, growth of $\mathrm{DBH}$ began to slow down significantly, the current and mean annual increment decreased too. The maximum of fir tree current annual increment in 100 years, as $1.07 \mathrm{~cm}$, the maximum mean annual increment showed in 113 years, as $0.3 \mathrm{~cm}$. Between 35 and 60 years, DBH growth began to accelerate, form 40 to 70 years, the growth of $\mathrm{DBH}$ achieved strong, then began falling, no significant decline was seen in mean annual increment growth. Spruce-fir DBH total increment is shown in Figure $3 \& 4$.

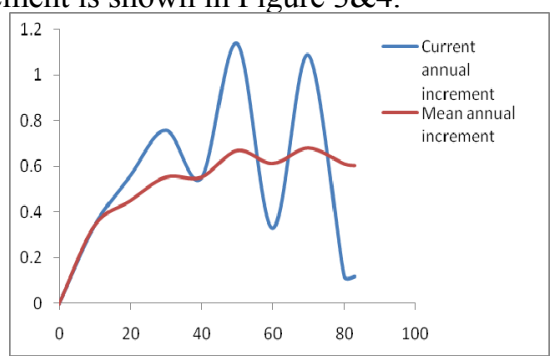

Figure 1. Spruce DBH current \& mean annual increment graph

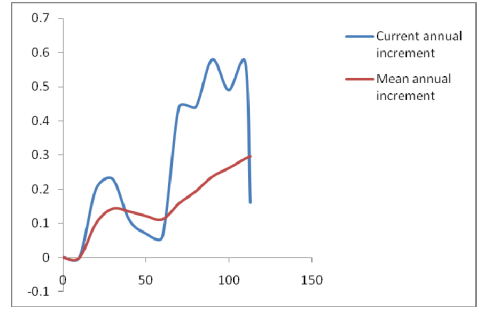

Figure 2. DBH current \& mean annual increment graph

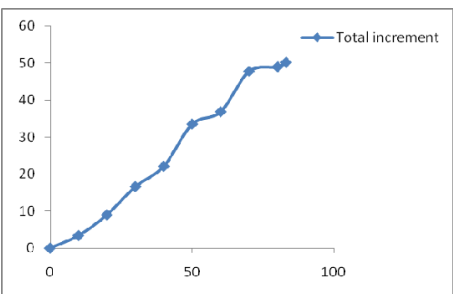

Figure 3. Spruce DBH total increment graph

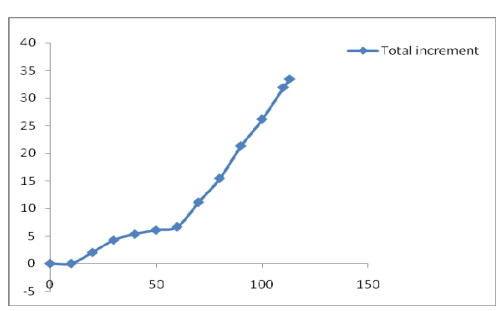

Figure 4. Fir DBH total increment graph

\section{C. analysis of spruce-fir height}

From growth table (Table I\&Table II) and the graph of height current and mean annual increment (Figure 3\& Figure 4) we know: The maximum height of spruce current annual increment in 30 years, as $0.7 \mathrm{~m}$ and mean annual increment in 40 , as $0.49 \mathrm{~m}$. At 45 years, spruce current \& mean annual increment intersected, that reached the quantitative maturity. In the 30 to 45 years, current annual increment of spruce began to slow down significantly, but the value had still higher than mean annual increment. After 45 years, mean annual increment declined, but its trend slow, current annual increment had dropped from $0.48 \mathrm{~m}$ to $0.1 \mathrm{~m}$, then although it had upward trend, the value was far less than mean annual increment. Before 75 years, fir tree current annual increment growth slowed, then arrived the peak value, as $0.66 \mathrm{~m}$, after 80 years, it sharply descended, at 90 years, fir current \& mean annual increment intersected, that reached the quantitative maturity. Mean annual increment of fir growth was relative slow, only in 70 to 80 years increased slightly to $0.16 \mathrm{~m}$, the growth remained this value. The height of Spruce-fir total increment is shown in Figure 3.1 and Fig5 


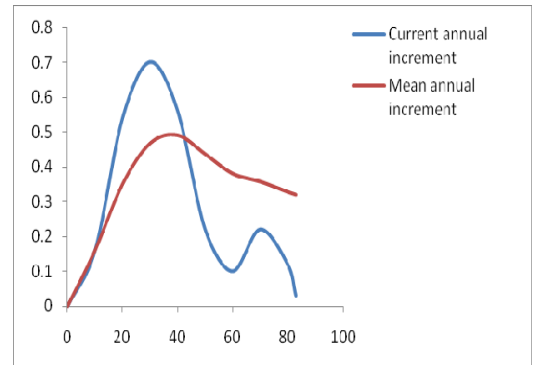

Figure 5. Spruce height current \& mean annual increment graph

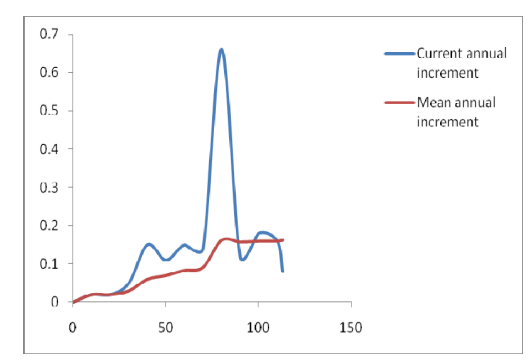

Figure 6. Fir height current $\&$ mean annual increment graph

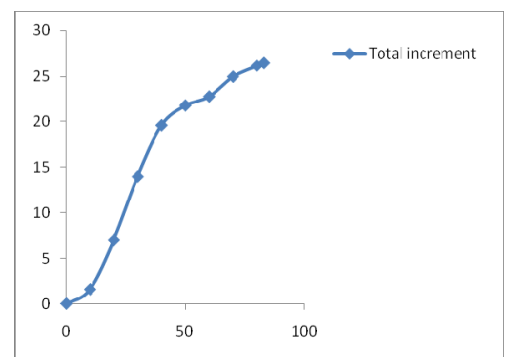

Figure 7. Spruce height total increment graph

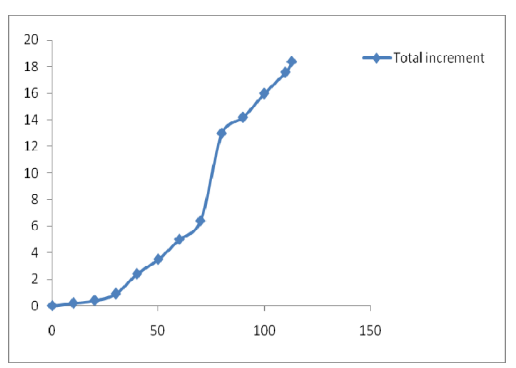

Figure 8. Fir height total increment graph

\section{D. analysis of spruce-fir volume}

Form growth table (Table I\&Table II) and the graph of volume current and mean annual increment (Figure $5 \&$ Figure 6) we know: spruce volume current annual increment relatively grew slow form 10 to 50 years, which reached maximum value in 80 years, as $0.2861 \mathrm{~m} 3$, then current annual increment sharply declined, mean annual volume growth was relatively slow trend. Fir volume current and mean annual increment unchanged before 70 years.
Between 70 and 110 years, volume current annual increment began to increase sharply, and in 110 years reached maximum value, as $0.1285 \mathrm{~m}^{3}$, mean annual increment began to increase also, but its rate of increase is far behind current annual increment. Spruce-fir volume total increment is shown in Figure 9and Fig10

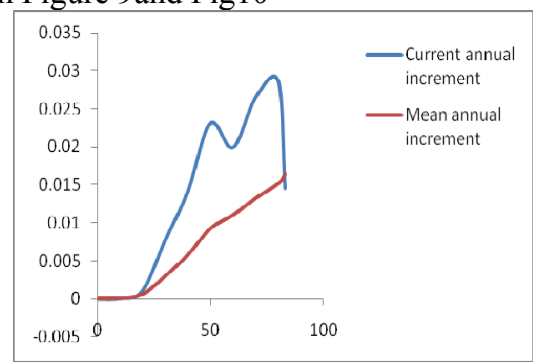

Figure 9. Spruce volume current \& mean annual increment graph

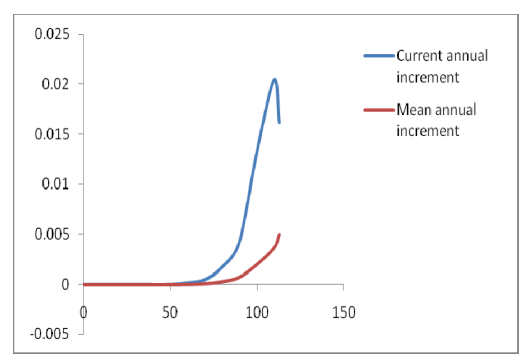

Figure 10. Fir volume current \& mean annual increment graph

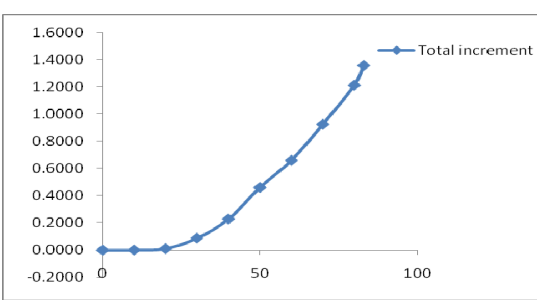

Figure 11. Spruce volume total increment graph

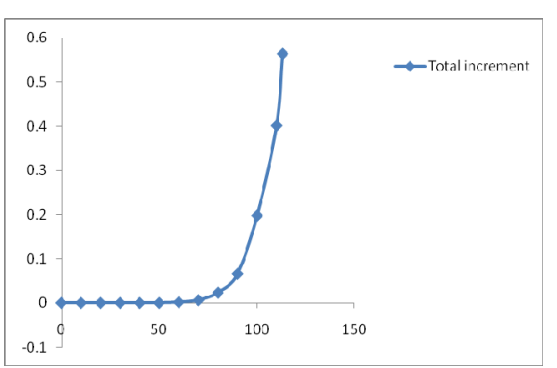

Figure 12. Fir volume total increment graph

\section{E. analysis of spruce-fir form factor}

From the graph of variety spruce-fir form factor (Figure 7\&Figure 8) we know: breast height form factor of spruce is 0.482 in 10years, after it undulates between 0.2 and 0.3 , which shows the change of spruce-fir form factor at a small range. Fir height form factor of spruce is 0.955 in 20 
years, 0.178 in 40 years, and then increased in50 years, after 50 years it kept between 0.2 and 0.3 .It shows that the change of tree sharpened degree not acute, and accords in normal law of forest growth.

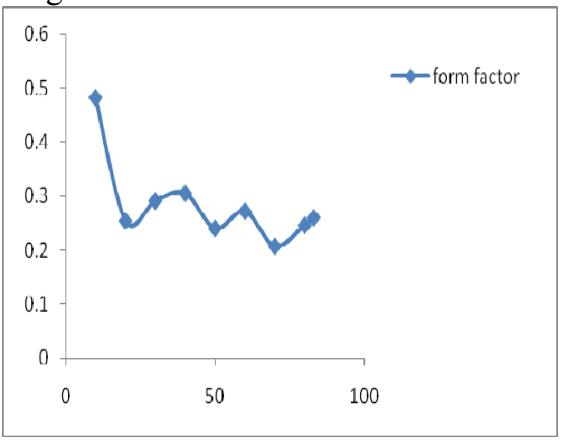

Figure 13. Spruce form factor graph

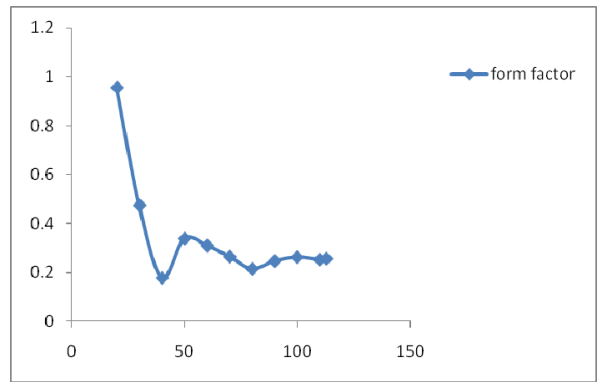

Figure 14. Fir form factor graph

\section{SPRUCE-FIR HEIGHT CURVE}

Using height denotes ordinate, breast diameter denotes abscissa, to printing diameter point in plot paper which every breast diameter corresponds height, and according the points to drawing a smooth curve, it can reflect the change of height with the diameter, this curve is called the tree height curve, and the equation is called height curve equation [7]. There are many domestic and international researches on tree height curve, different regions and species corresponding to tree height curve is different. Many of the domestic researches about tree height curve of Abies ziyuanensis, Pinus densiflora, Pinus kesiya [8-9]. Common tree height curve equation includes Logarithmic, Quadratic, Growth and Exponential etc (Table III). Using spruce-fir height denotes ordinate, breast diameter denotes abscissa to printing height curve and SPSS to analyzing the date. Through maximum correlation coefficient (R2) and minimum residual variance checks up the result.

TABLE III. HEIGHT CURVE EQUATION

\begin{tabular}{cc}
\hline Height curve equation & Expression \\
\hline Logarithmic & $H=b_{0}+b_{1} \ln D$ \\
Quadratic & $H=b_{0}+b_{1} D+b_{2} D^{2}$ \\
Growth & $H=\exp \left(b_{0}+b_{1} D\right)$ \\
Exponential & $H=b_{0}\left(\exp b_{1} D\right)$ \\
\hline
\end{tabular}

$H$ is height, $D$ is diameter, $e$ is Natural logarithm, $\mathrm{b}_{0}$ is constant,$b_{1} 、 b_{2}$ is equation parameters.

The result shows that Quadratic can be a good sprucefir tree fitting equation, and their correlation coefficient are $0.985,0.982$; another one is Logarithmic, their correlation coefficient are spruce 0.979, fir 0.935. But Growth and Exponential can't good fit equation, their correlation coefficient are lower than Quadratic and Logarithmic. Spruce-fir height curve and the relation of height curve equation and correlation coefficient vided Figure 9, Figure 10\&Table IV.

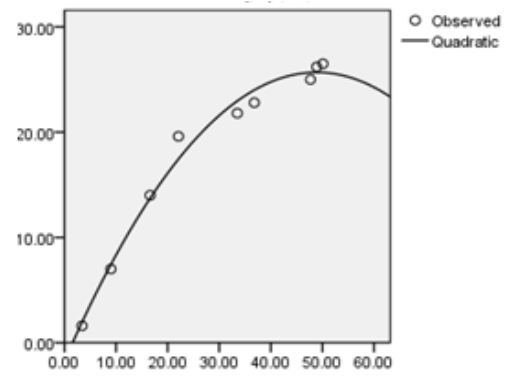

Figure 15. spruce height curve

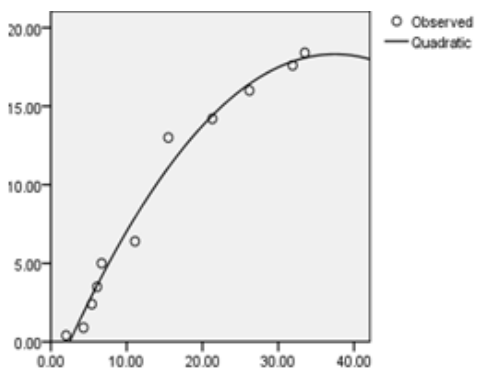

Figure 16. fir height curve

TABLE IV. SPRUCE-FIR FItTING EQUATION OF SPRUCE-FIR AND CORRELATION COEFFICIENT

\begin{tabular}{|c|c|c|c|}
\hline & Equation & Fitting Equation & R2 \\
\hline \multirow{2}{*}{ Spruce } & Quadratic & $\begin{array}{c}\mathrm{H}=-1.736+1.121 \mathrm{D}- \\
0.11 \mathrm{D} 2\end{array}$ & 0.985 \\
& & $\mathrm{H}=-11.76+9.616 \operatorname{lnD}$ & 0.979 \\
\hline \multirow{2}{*}{ Fir } & Qogarithmic & $\begin{array}{c}\mathrm{H}=-2.687+1.121 \mathrm{D}- \\
0.15 \mathrm{D} 2\end{array}$ & 0.982 \\
\hline & Logarithmic & $\mathrm{H}=-8.408+7.32 \ln \mathrm{D}$ & 0.935 \\
\hline
\end{tabular}

\section{CONCLUSION}

After analyzing growth of spruce-fir DBH and height, we found that early growth of spruce and fir are very slow, and DBH current annual increment reached maximum in 50 and 100 years, $1.14 \mathrm{~cm}$ and $1.07 \mathrm{~cm}$ respectively. $\mathrm{DBH}$ growth was fastest between 40 and 70 years for spruce, and between 60and 110 years for fir, both began to slow down significantly. Height current annual increment reached maximum in 30 and 75 years, curves $0.49 \mathrm{~m}$ and $0.66 \mathrm{~m}$ respectively. Spruce current annual increment and mean annual increment intersected in 45 years, fir intersected in 77 years. During volume growth of spruce- 
fir, current annual increment was much higher than mean annual increment. Quadratic equation could fit spruce-fir height curve better, following is Logarithmic.

The data used in this study is not enough to describe the growth process of spruce-fir broadly. Therefore, there exist some limitations in the models, which expected to be tested, revised and improved in future.

\section{REFERENCES}

[1] ZHAO Jun-hui; LIU Yan; ZHANG Hui-dong; KANG Xin-gang. Comparison of height-diameter models for main species in natural forest of Changbai Mountains. Journal of Zhejiang Forestry College [J], 2009, 26(6): PP: 865-869.

[2] LI Wen-hua; LUO Tian-xiang. Productivity patterns and mathematical models of spruce-fir forests in China Acta ecological sinica [J], 1997, 17(5): PP: 511-518.

[3] HAN Jing-jun; LUO Chun-ju. Study on soil under spruce-fir forests in north Changbai Mountains. Journal of Beijing Forestry University [J], 1999, 21(6): PP: 35-39.
[4] DENG Hong-bin; HAO Zhan-qing; WANG Qing-li; JIANG Ping. Study on Height Growth Model of Pinus koraiensis. Chinese journal of ecology [J], 1999, 18(3): PP: 19-22.

[5] MENG Xian-yu. Forest Mensuration (the 3rd edition). 2006: China Forestry Publishing House.

[6] JIANG De-hong. Study on growth rules of Pinus elliotii. HUNAN forestry science \& technology [J], 2007(3): PP: 10-12.

[7] CHENG Jian-zheng. Fitting test and assessment of height curve based on Matlab. Forest inventory and planning [J], 2007, 32(3):1-3.

[8] LAI Qiao-ling; XU Hui; YANG Wei-min. Application of nonparametric estimation method in establishing height diameter curves of trees. Journal of Beijing Forestry University [J], 2006, 28(4): PP: 77-81.

[9] XU Yue; CHEN Chang-hua; JIANG Zhi-fu; BO Hai-bo; LONG Miao-ling; CUI Tong-qi. Study on correlated models between the diameter at breast height and the tree height of natural red pine. Forest inventory and planning [J], 2008, 33(3) PP: 56-58.

TABLE I. SPRUCE TREE GROWTH TABLE

\begin{tabular}{|c|c|c|c|c|c|c|c|c|c|c|c|}
\hline \multirow[t]{2}{*}{ Age } & \multicolumn{3}{|c|}{$\begin{array}{l}\mathrm{DBH} \\
(\mathrm{cm})\end{array}$} & \multicolumn{3}{|c|}{$\begin{array}{c}\text { Height } \\
(\mathrm{m})\end{array}$} & \multicolumn{3}{|c|}{$\begin{array}{l}\text { Volume } \\
\text { (m3) }\end{array}$} & & \multirow[t]{2}{*}{$\begin{array}{l}\text { Form } \\
\text { factor }\end{array}$} \\
\hline & $\begin{array}{c}\text { Total } \\
\text { increment }\end{array}$ & $\begin{array}{c}\text { Current } \\
\text { annual } \\
\text { increment }\end{array}$ & $\begin{array}{c}\text { Mean } \\
\text { annual } \\
\text { increment }\end{array}$ & $\begin{array}{c}\text { Total } \\
\text { increment }\end{array}$ & $\begin{array}{c}\text { Current } \\
\text { annual } \\
\text { increment }\end{array}$ & $\begin{array}{c}\text { Mean } \\
\text { annual } \\
\text { increment }\end{array}$ & $\begin{array}{c}\text { Total } \\
\text { increment }\end{array}$ & $\begin{array}{c}\text { Current } \\
\text { annual } \\
\text { increment }\end{array}$ & $\begin{array}{c}\text { Mean } \\
\text { annual } \\
\text { increment }\end{array}$ & $\begin{array}{c}\text { Increment } \\
\text { rate } \\
\% \\
\end{array}$ & \\
\hline 10 & 3.4 & 0.34 & 0.34 & 1.6 & 0.16 & 0.16 & 0.0007 & 0.00007 & 0.00007 & 20.0 & 0.482 \\
\hline 20 & 9 & 0.56 & 0.45 & 7 & 0.54 & 0.35 & 0.0113 & 0.00106 & 0.00057 & 17.7 & 0.254 \\
\hline 30 & 16.6 & 0.76 & 0.55 & 14 & 0.7 & 0.47 & 0.0883 & 0.00770 & 0.00294 & 15.5 & 0.291 \\
\hline 40 & 22.1 & 0.55 & 0.55 & 19.6 & 0.56 & 0.49 & 0.2291 & 0.01408 & 0.00573 & 8.9 & 0.305 \\
\hline 50 & 33.5 & 1.14 & 0.67 & 21.8 & 0.22 & 0.44 & 0.4602 & 0.02311 & 0.00920 & 6.7 & 0.240 \\
\hline 60 & 36.8 & 0.33 & 0.61 & 22.8 & 0.1 & 0.38 & 0.6591 & 0.01990 & 0.01099 & 3.6 & 0.272 \\
\hline 70 & 47.7 & 1.09 & 0.68 & 25 & 0.22 & 0.36 & 0.9240 & 0.02648 & 0.01320 & 3.3 & 0.207 \\
\hline 80 & 48.9 & 0.12 & 0.61 & 26.2 & 0.12 & 0.33 & 1.2101 & 0.02861 & 0.01513 & 2.7 & 0.246 \\
\hline 83 & 50.1 & 0.12 & 0.60 & 26.5 & 0.03 & 0.32 & 1.3555 & 0.01455 & 0.01633 & 1.1 & 0.260 \\
\hline skin & 52.2 & & & 26.5 & & & 1.5025 & & & & 0.265 \\
\hline
\end{tabular}

TABLE II. FIR TREE GROWTH TABLE

\begin{tabular}{|c|c|c|c|c|c|c|c|c|c|c|c|}
\hline \multirow[t]{2}{*}{ Age } & \multicolumn{3}{|c|}{$\begin{array}{l}\text { DBH } \\
(\mathrm{cm})\end{array}$} & \multicolumn{3}{|c|}{$\begin{array}{l}\text { Height } \\
(\mathrm{m})\end{array}$} & \multicolumn{3}{|c|}{$\begin{array}{l}\text { Volume } \\
\text { (m3) }\end{array}$} & & \multirow[t]{2}{*}{$\begin{array}{l}\text { Form } \\
\text { factor }\end{array}$} \\
\hline & $\begin{array}{c}\text { Total } \\
\text { increment }\end{array}$ & $\begin{array}{c}\text { Current } \\
\text { annual } \\
\text { increment }\end{array}$ & $\begin{array}{c}\text { Mean } \\
\text { annual } \\
\text { increment }\end{array}$ & $\begin{array}{c}\text { Total } \\
\text { increment }\end{array}$ & $\begin{array}{c}\text { Current } \\
\text { annual } \\
\text { increment } \\
\end{array}$ & $\begin{array}{c}\text { Mean } \\
\text { annual } \\
\text { increment }\end{array}$ & $\begin{array}{c}\text { Total } \\
\text { increment }\end{array}$ & $\begin{array}{c}\text { Current } \\
\text { annual } \\
\text { increment } \\
\end{array}$ & $\begin{array}{c}\text { Mean } \\
\text { annual } \\
\text { increment }\end{array}$ & $\begin{array}{c}\text { Increment } \\
\text { rate } \\
\% \\
\end{array}$ & \\
\hline 10 & 0 & 0 & 0 & 0.2 & 0.02 & 0.02 & 0 & 0 & 0 & 0 & \\
\hline 20 & 2 & 0.2 & 0.10 & 0.4 & 0.02 & 0.02 & 0.00012 & 0.00001 & 0.00001 & 20.0 & 0.955 \\
\hline 30 & 4.3 & 0.43 & 0.14 & 0.9 & 0.05 & 0.03 & 0.00062 & 0.00005 & 0.00002 & 13.5 & 0.475 \\
\hline 40 & 5.4 & 0.34 & 0.14 & 2.4 & 0.15 & 0.06 & 0.00098 & 0.00004 & 0.00002 & 4.5 & 0.178 \\
\hline 50 & 6.1 & 0.18 & 0.12 & 3.5 & 0.11 & 0.07 & 0.00347 & 0.00025 & 0.00007 & 11.2 & 0.339 \\
\hline
\end{tabular}

